\title{
Wind Power Price Trends in the United States: Struggling to Remain Competitive in the Face of Strong Growth
}

\author{
Mark Bolinger* and Ryan Wiser \\ Lawrence Berkeley National Laboratory
}

Berkeley Lab's work on this article was funded by the Wind \& Hydropower Technologies Program, Office of Energy Efficiency and Renewable Energy of the U.S. Department of Energy under Contract No. DE-AC02-05CH11231.

*Corresponding author. Lawrence Berkeley National Laboratory, 1 Cyclotron Road, Berkeley, California, USA. Tel: 603-795-4937. E-mail: mabolinger@lbl.gov

\begin{abstract}
The amount of wind power capacity being installed globally is surging, with the United States the world leader in terms of annual market share for three years running (2005-2007). The rapidly growing market for wind has been a double-edged sword, however, as the resulting supply-demand imbalance in wind turbines, along with the rising cost of materials and weakness in the U.S. dollar, has put upward pressure on wind turbine costs, and ultimately, wind power prices. Two mitigating factors - reductions in the cost of equity provided to wind projects and improvements in project-level capacity factors - have helped to relieve some of the upward pressure on wind power prices over the last few years. Because neither of these two factors can be relied upon to further cushion the blow going forward, policymakers should recognize that continued financial support may be necessary to sustain the wind sector at its current pace of development, at least in the near term. Though this article emphasizes developments in the U.S. market for wind power, those trends are similar to, and hold implications for, the worldwide wind power market.
\end{abstract}

Keywords: wind power, cost trends, price trends

\subsection{Introduction}

Driven by concerns over climate and energy security, the rising cost of fossil fuels, and even economic development interests, wind power is booming worldwide, with nearly $20 \mathrm{GW}$ of new wind capacity installed in 2007. Although European countries have led the charge over most of the past decade, more recently the United States has become the fastest-growing wind power market in the world in terms of new installed capacity, followed by European stalwarts Germany and Spain, as well as the up-and-coming Asian markets of China and India (BTM Consult, 2008). With major development now occurring on several continents, wind power is becoming a truly global generation resource, and is widely expected to continue growing rapidly into the future (see, e.g., IEA, 2007; BTM Consult, 2008; GWEC, 2008).

Yet at the same time that the growth of wind power is accelerating, a confluence of factors is putting upward pressure on wind project costs and, by extension, wind power prices. These 
include strong demand for wind turbines in excess of current supply, ${ }^{1}$ the rising cost of materials and energy used to manufacture wind turbines (IHS CERA, 2008), and - in the United States, at least - currency weakness. Though not unique to wind power - cost pressures are an industrywide concern in the power sector (see, e.g., Chupka and Basheda, 2007) - rising costs nevertheless threaten to hamper the future growth of the wind sector. These developments, in turn, should be a consideration for policymakers intent on stimulating the continued growth of wind power.

Within the context of what is currently the world's fastest-growing wind market - the U.S. - this article provides a detailed and comprehensive picture of key cost trends in the U.S. wind power market, with important implications for market participants and policymakers. Drawing upon data-rich sources of wind turbine pricing, wind project costs, and wind power prices, ${ }^{2}$ this article reviews long-term historical trends and, perhaps more importantly, demonstrates the recent cost pressures facing wind and how rising costs impact wind's competitiveness. Though this article does not offer a long-term forecast of future wind costs or competitiveness, understanding historical and current trends can help to inform such forecasts.

To put the material on wind cost and pricing trends in perspective, the article begins with an overview of growth in the wind power sector both globally and specifically in the U.S. It then draws upon empirical data from the U.S. to demonstrate recent increases in wind turbine pricing, installed project costs, and wind power prices, and does so within the context of the longer-term historical decline in these measures. Next, it discusses two factors - improved financing terms and project performance - that have helped to mitigate the impact of rising costs on wind power prices in the United States in recent years, but that may not be able to sustain this role going forward. Finally, the article concludes by assessing wind's current competitiveness in the U.S. in the face of these cost pressures, and by offering some brief implications of this work for forecasters and policymakers.

\subsection{Overview of Wind Power Growth}

\subsection{Installation Trends}

Nearly $20 \mathrm{GW}$ of new wind capacity was installed worldwide in 2007 . This was the highest volume ever achieved in a single year, and brought the cumulative total to approximately $94 \mathrm{GW}$ (Table 1 and Figure 1). So far this decade (through 2007), cumulative wind power capacity has grown by an average of $27 \%$ per year worldwide (with a standard deviation of $5 \%$ ).

For the third straight year, the United States led the world in 2007 in terms of newly installed ongrid wind capacity, adding in excess of $5.3 \mathrm{GW}$, which itself represents a $\$ 9$ billion investment (in real 2007 dollars). ${ }^{3}$ This more-than-doubled the previous U.S. installation record set in 2006,

\footnotetext{
${ }^{1}$ Most wind turbine manufacturers' order books are reportedly filled for several years in the future, and profit margins among both wind turbine manufacturers and component suppliers have risen as well (Bolinger, 2008).

${ }^{2}$ Much of the data summarized in this article comes from Wiser and Bolinger (2008).

${ }^{3}$ The $\$ 9$ billion investment figure is calculated by multiplying the $5.3 \mathrm{GW}$ of newly installed wind by an average installed cost of around $\$ 1,700 / \mathrm{kW}$ (from Figure 8).
} 
and brought the cumulative U.S. total to roughly $17 \mathrm{GW}$ (Table 1 and Figure 2). As it has globally, cumulative wind power capacity in the U.S. has grown by an average of $27 \%$ per year so far this decade (through 2007). The variability of growth in U.S. wind power capacity over this period, however, has been significantly larger (with a standard deviation of around 20\%) than the variability of global growth. ${ }^{4}$

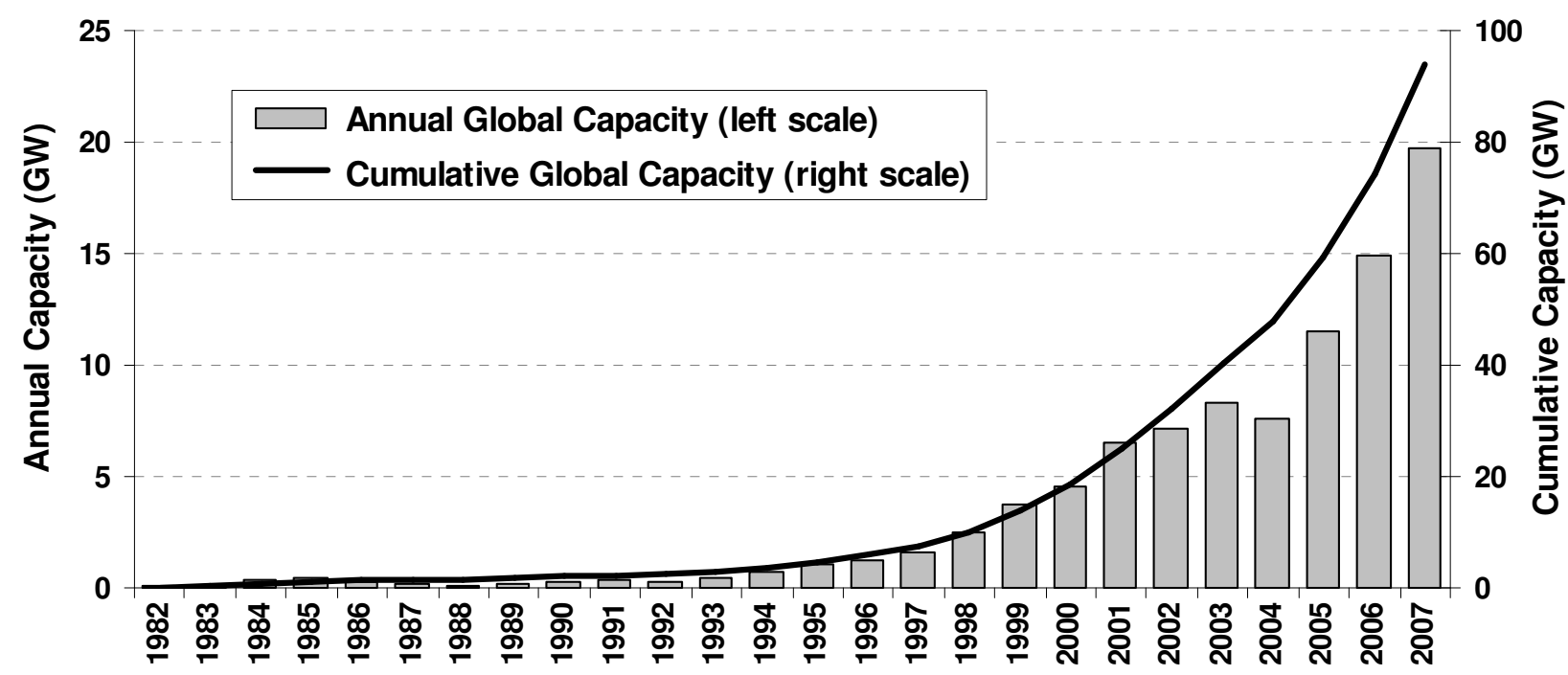

Source: Wiser and Bolinger, 2008

Figure 1. Annual and Cumulative Growth in Global Wind Capacity

Table 1. International Rankings of Wind Power Capacity

\begin{tabular}{|lrlr|}
\hline $\begin{array}{c}\text { Incremental Capacity } \\
(\mathbf{2 0 0 7}, \mathbf{M W )}\end{array}$ & \multicolumn{2}{c|}{$\begin{array}{c}\text { Cumulative Capacity } \\
\text { (end of 2007, MW) }\end{array}$} \\
\hline United States & $\mathbf{5 , 3 2 9}$ & Germany & 22,277 \\
China & 3,287 & United States & $\mathbf{1 6 , 9 0 4}$ \\
Spain & 3,100 & Spain & 14,714 \\
Germany & 1,667 & India & 7,845 \\
India & 1,617 & China & 5,875 \\
France & 888 & Denmark & 3,088 \\
Italy & 603 & Italy & 2,721 \\
Portugal & 434 & France & 2,471 \\
United Kingdom & 427 & United Kingdom & 2,394 \\
Canada & 386 & Portugal & 2,150 \\
Rest of World & 2,138 & Rest of World & 13,591 \\
\hline TOTAL & $\mathbf{1 9 , 8 7 6}$ & TOTAL & $\mathbf{9 4 , 0 3 0}$ \\
\hline
\end{tabular}

Source: Wiser and Bolinger, 2008

\footnotetext{
${ }^{4}$ Although one might expect greater variability within a single country than globally (due to the smoothing effect across countries), it is nevertheless worth noting that highly variable growth within the US wind power market has discouraged greater manufacturing investment and made it difficult to plan for growth in general.
} 


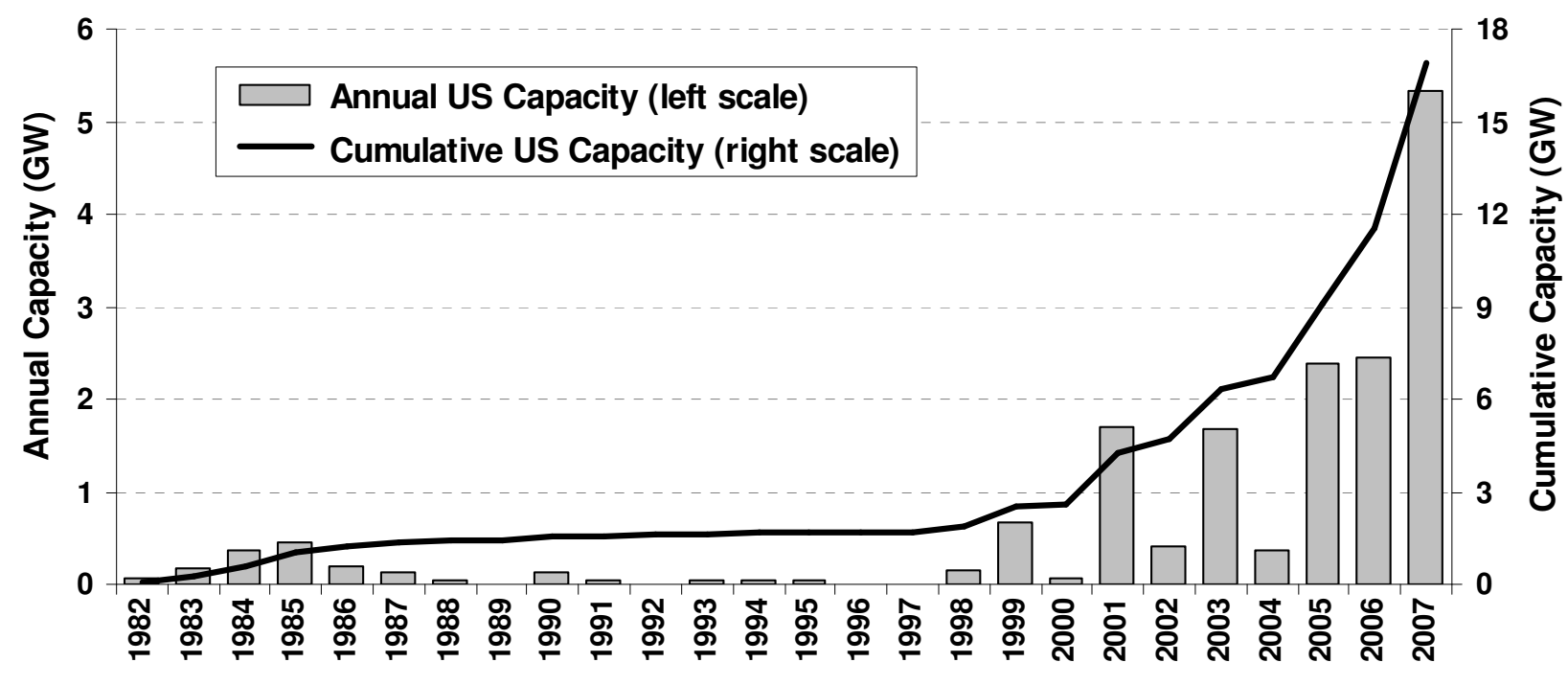

Source: Wiser and Bolinger, 2008

Figure 2. Annual and Cumulative Growth in U.S. Wind Power Capacity

No country, in any single year, has previously added the volume of wind capacity that was added to the U.S. electrical grid in 2007. This record-shattering installation pace in the United States accounted for roughly 27\% of the worldwide wind market in 2007, up from 16\% in 2006 (Figure 3). In cumulative terms, the United States ended the year with $18 \%$ of worldwide wind capacity, moving ahead of Spain, but still second to Germany (Figure 3 and Table 1). As recently as 1990, the U.S. accounted for as much as $75 \%$ of cumulative wind capacity worldwide (Figure 3); that it now contributes less than $20 \%$ of cumulative capacity is in part a result of limited wind power installations in the U.S. throughout most of the 1990s, but also demonstrates the increasingly global spread of the wind power market.

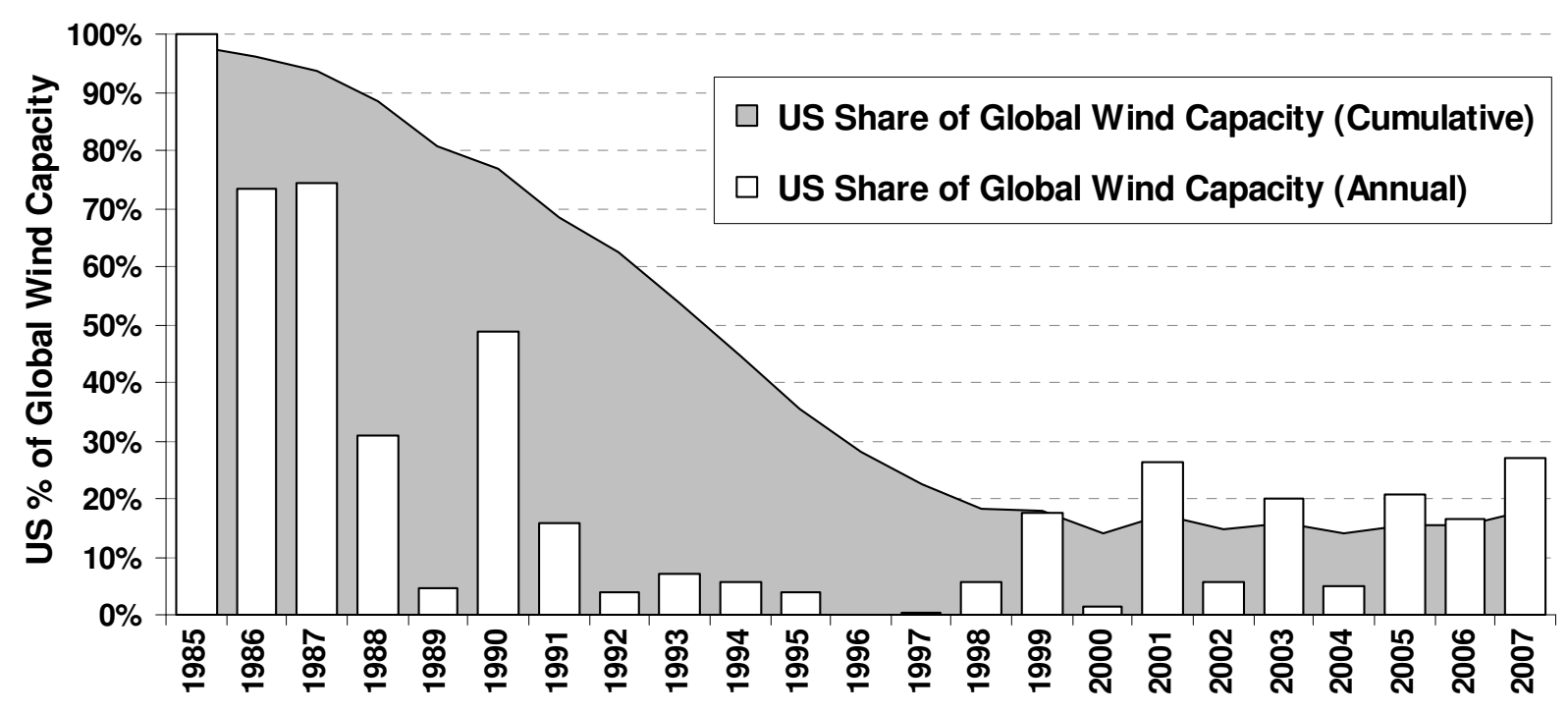

Source: Wiser and Bolinger, 2008

Figure 3. U.S. Share of Global Wind Capacity 


\subsection{Growth Drivers in the United States}

The growth of wind in the United States has been driven primarily by Federal tax incentives, state renewables portfolio standards (RPS) and other state-level policies, concern about global climate change (despite the lack of a Federal climate policy), and continued uncertainty about the future costs and liabilities of natural gas- and coal-fired power plants.

Most notably, the Federal production tax credit (PTC) for wind and other eligible renewable resources provides a 10-year, inflation-adjusted credit against income taxes, and stood at $\$ 20 / \mathrm{MWh}$ in 2007. With most wind project owners falling into the 35\% Federal tax bracket, the \$20/MWh PTC in 2007 equates to roughly $\$ 30.8 / \mathrm{MWh}$ of pre-tax revenue: $\$ 20 /(1-35 \%)=$ $\$ 30.8$. Levelized over a 20-year period (i.e., the typical modeled life of a wind project), this 10 year incentive of \$30.8/MWh equates to roughly \$20/MWh of pre-tax revenue (in constant 2007 dollars), which in turn means that if the PTC were not available, wind power prices would have to rise by about $\$ 20 / \mathrm{MWh}$ in order to meet the return targets of project investors. As such, the PTC plays an important role in making wind power competitive with other forms of generation in the United States. ${ }^{5}$

The importance of the PTC to the U.S. wind market can be seen in the yearly boom-and-bust cycle that characterized the market from 1999 through 2004 (Figure 2). This cycle was caused by several expirations and subsequent short-term extensions of the PTC, creating uncertainty in the marketplace. Since late 2004, however, the PTC has been continuously available to projects placed in service through the end of 2009, which has led to three consecutive years of record growth, with 2008 expected to be the fourth.

State-level policies also play a substantial role in directing the location and amount of wind development. From 1999 through 2007, for example, more than 55\% of the wind power capacity built in the U.S. was located in states with RPS policies; in 2007 alone, this proportion was more than $75 \%$ (Wiser and Barbose, 2008). Utility resource planning requirements in Western and Midwestern states have also helped spur wind additions in recent years, especially as those resource plans increasingly consider the high and uncertain price of natural gas and the increasing likelihood of state and federal climate legislation (Barbose et al., 2008; Bolinger and Wiser, 2005). Growing voluntary customer demand for "green" power (Bird et al., 2007), state renewable energy funds, and a variety of state tax and other incentives have also played supportive roles (Bird et al., 2005). Finally, concerns about the possible impacts of global climate change are fueling interest by states, regions, and the federal government to implement carbon reduction policies (see, e.g., Lusey and Sperling, 2008; Byrne et al., 2007), a trend that is likely to increasingly underpin wind power expansion in the years ahead.

\subsection{Wind Is a Growing Contributor to the Power Mix}

As a result of these and other drivers, wind power now represents one of the largest new sources of electric capacity additions in the United States. For the third consecutive year, wind power

\footnotetext{
${ }^{5}$ Also available at the Federal level is 5-year accelerated depreciation for Federal income tax purposes. Compared to the 15-year depreciation schedule available to some fossil power plants in the U.S., this accelerated tax depreciation schedule offers an incentive to wind projects equivalent to roughly $\$ 14 / \mathrm{MWh}$.
} 
was the second-largest new resource added to the U.S. electrical grid in terms of nameplate capacity in 2007 (with $5.3 \mathrm{GW}$ added), behind the $7.5 \mathrm{GW}$ of new natural gas plants, but ahead of the $1.4 \mathrm{GW}$ of new coal (Figure 4). New wind plants contributed roughly $35 \%$ of the new nameplate capacity added to the U.S. electrical grid in 2007, compared to $19 \%$ in $2006,12 \%$ in 2005, and less than 4\% from 2000 through 2004. Over the entire period from 2000-2007, wind contributed $5 \%$ of all new capacity in the U.S. Though not shown in the figure, the corresponding data for Europe are even more-impressive: wind contributed $40 \%$ of all new electrical capacity added in the European Union in 2007, and has contributed $30 \%$ of all new capacity added during the period of 2000-2007 (EWEA, 2008).

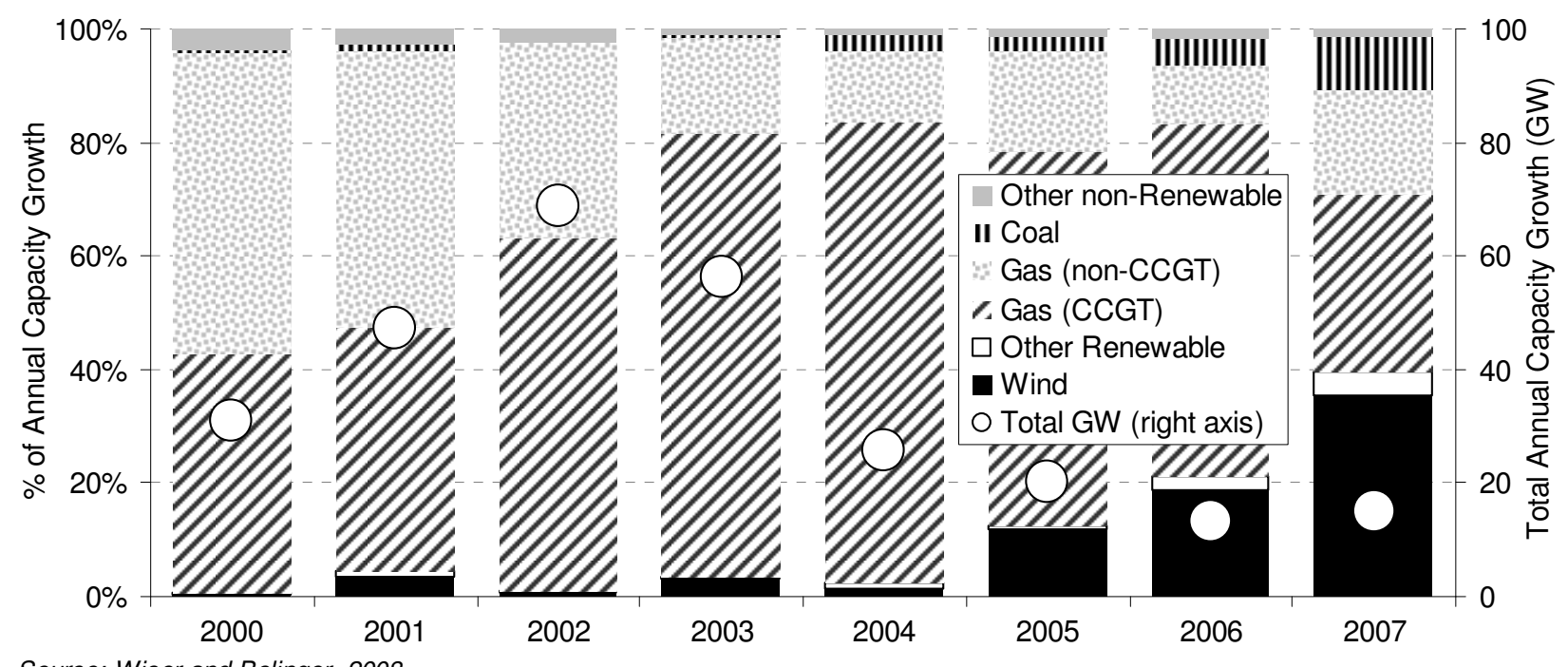

Source: Wiser and Bolinger, 2008

Figure 4. Relative Contribution of Resources to Annual Capacity Growth in the U.S.

Not surprisingly, then, several European countries are beginning to achieve relatively high levels of wind power penetration in their electricity grids. Focusing only on the 20 countries with the most installed wind capacity, Figure 5 shows that end-of-2007 installed wind is projected to supply roughly $20 \%$ of Denmark's electricity demand (somewhat less than the previous year), $12 \%$ of Spain's (up by $2.2 \%$ from the previous year), $9 \%$ of Portugal's (up by $1.6 \%$ ), $8 \%$ of Ireland's (up by $0.4 \%$ ), and $7 \%$ of Germany's (also up by $0.4 \%$ ). In contrast, the cumulative wind capacity installed in the United States at the end of 2007 would, in an average year, be able to supply just $1.2 \%$ of the nation's electricity consumption (up by $0.4 \%$ from the previous year) the same as wind's estimated $1.2 \%$ contribution to electricity consumption on a worldwide basis.

Despite its rather modest current penetration rate, the U.S. wind industry has its eyes on loftier goals. In May 2008, the U.S. Department of Energy (in conjunction with the American Wind Energy Association and others) released a report assessing the technical and economic feasibility of achieving 20\% wind penetration by 2030 (U.S. Department of Energy, 2008). Though much will need to be accomplished in order to achieve this level of wind penetration, the report found no fundamental barriers to reaching $20 \%$ wind over this timeframe. 


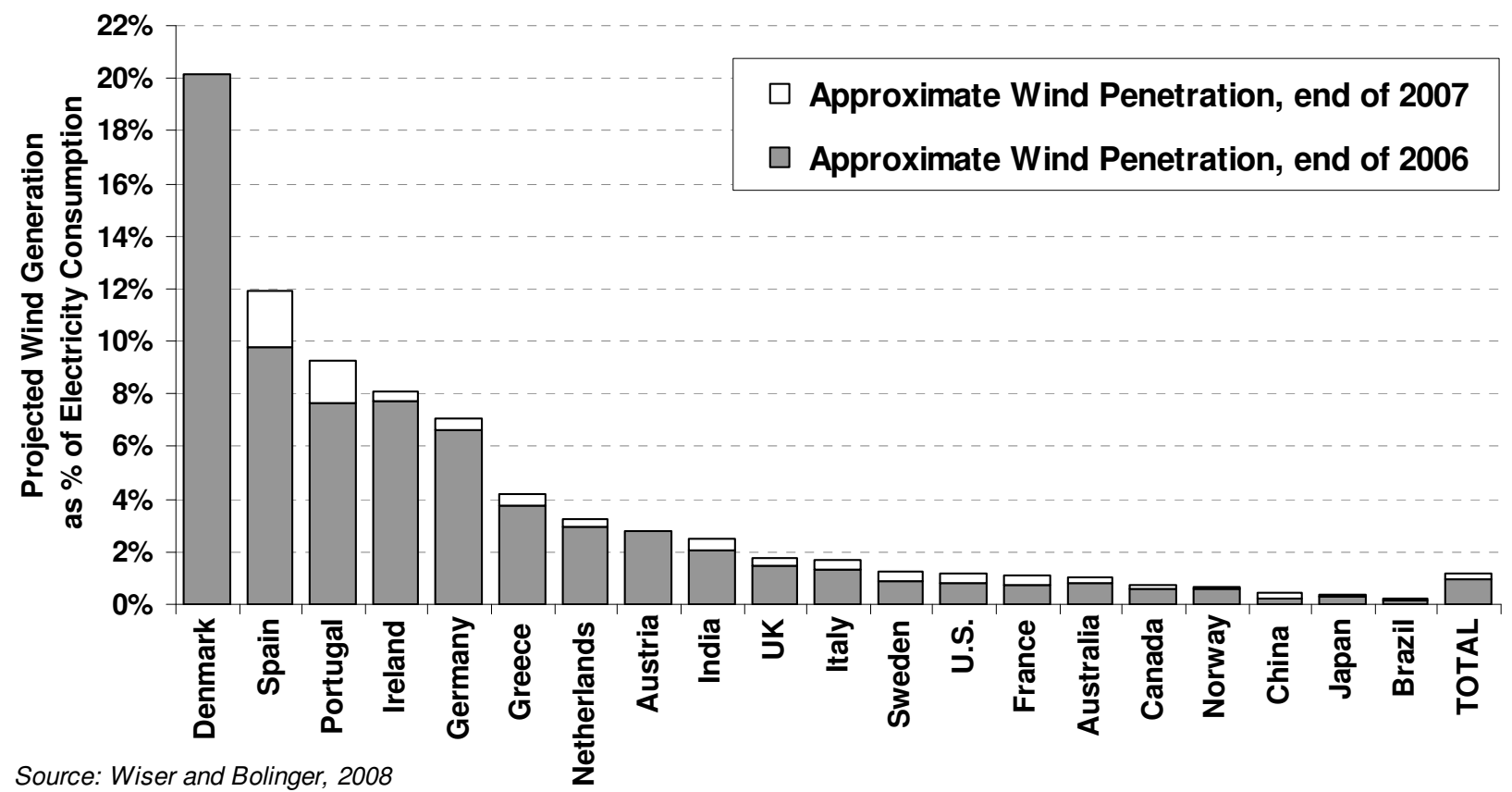

Figure 5. Approximate Wind Power Penetration in the Twenty Countries with the Most Installed Wind Capacity

In fact, based solely on the amount of wind power capacity currently working its way through key wind-relevant transmission interconnection queues across the United States, the industry appears, at least superficially, to be well on its way towards the $300+\mathrm{GW}$ of wind required to achieve $20 \%$ wind penetration. At the end of 2007 , there were $225 \mathrm{GW}$ of wind power capacity within these interconnection queues (i.e., having started the process of grid interconnection) more than 13 times the installed wind capacity in the U.S. at that time (Wiser and Bolinger, 2008). Moreover, this planned wind capacity represented roughly half of all generating capacity within these queues at that time, and twice as much capacity as the next-largest resource in these queues, natural gas (Figure 6). Although many of these planned projects are still very early in the development process, and a large number are unlikely to achieve commercial operations any time soon (if at all), the $225 \mathrm{GW}$ figure is nevertheless astounding, and provides an indication of the increasingly important role that wind may play within the nation's power mix. 


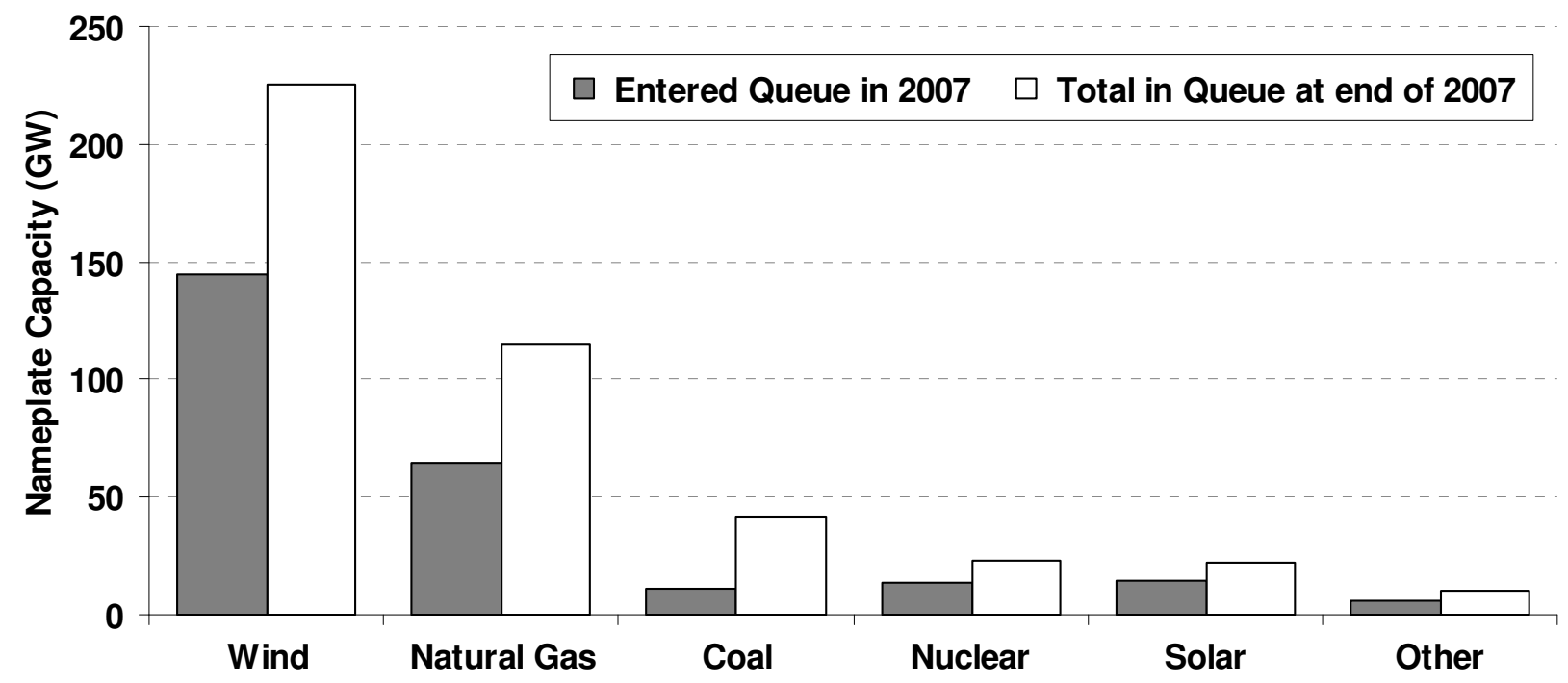

Source: Wiser and Bolinger, 2008

Figure 6. Nameplate Resource Capacity in Eleven Major Interconnection Queues

\subsection{Increasing Cost Pressures Threaten To Slow the Growth of Wind Power}

Although the wind power industry appears to be on solid footing in the United States, a shortage of wind turbines and turbine components, along with rising materials costs and weakness in the U.S. dollar has, in recent years, placed upward pressure on wind turbine prices, installed wind project costs, and, ultimately, wind power prices. ${ }^{6}$ Higher costs and prices, in turn, threaten to dampen the growth of the wind sector. Within the broader historical context of declining costs and prices, this section follows these more-recent cost increases through the development pipeline, from turbines to installed project costs to wind power prices.

\subsection{Turbine Prices}

Berkeley Lab has gathered data on 55 transactions for wind turbines destined for projects in the United States; these transactions range from single-turbine purchases to large frame agreements that far exceed $300 \mathrm{MW}$. In total, these transactions sum to nearly $20 \mathrm{GW}$ of wind capacity (not all of which is operational - some will be installed in future years), with announcement dates that span a time period from 1998 through mid-2008.

Figure 7 depicts the reported wind turbine prices for these transactions. ${ }^{7}$ Since hitting a nadir of roughly $\$ 700 / \mathrm{kW}$ in the $2000-2002$ period, turbine prices have doubled on average. In 2008 ,

\footnotetext{
${ }^{6}$ Although industry consolidation and resulting market power might also be perceived as potential cost drivers, most of the consolidation in the industry to date has occurred at the developer, rather than turbine manufacturer, level. In other words, turbine buyers, rather than turbine sellers, have been consolidating, in large part in response to the need for greater capitalization in order to secure turbines in a tight supply environment. If anything, competition among turbine manufacturers has increased, particularly in the U.S., as new entrants have emerged, both from Europe (e.g., Nordex or Acciona entering the North American market) and to the sector in general (e.g., Clipper Windpower commencing turbine production).

${ }^{7}$ Sources of transaction price data vary, but most derive from press releases and news reports. Wind turbine transactions differ in the services offered (e.g., whether towers and installation are provided, the length of the service
} 
wind turbine transaction prices ranged from a low of $\$ 900 / \mathrm{kW}$ to a high of $\$ 1960 / \mathrm{kW}$, with a capacity-weighted average of roughly $\$ 1,420 / \mathrm{kW}$. In general, the larger turbine transactions have been priced at the lower end of the price range, while the smallest transactions suffer from diseconomies of scale.

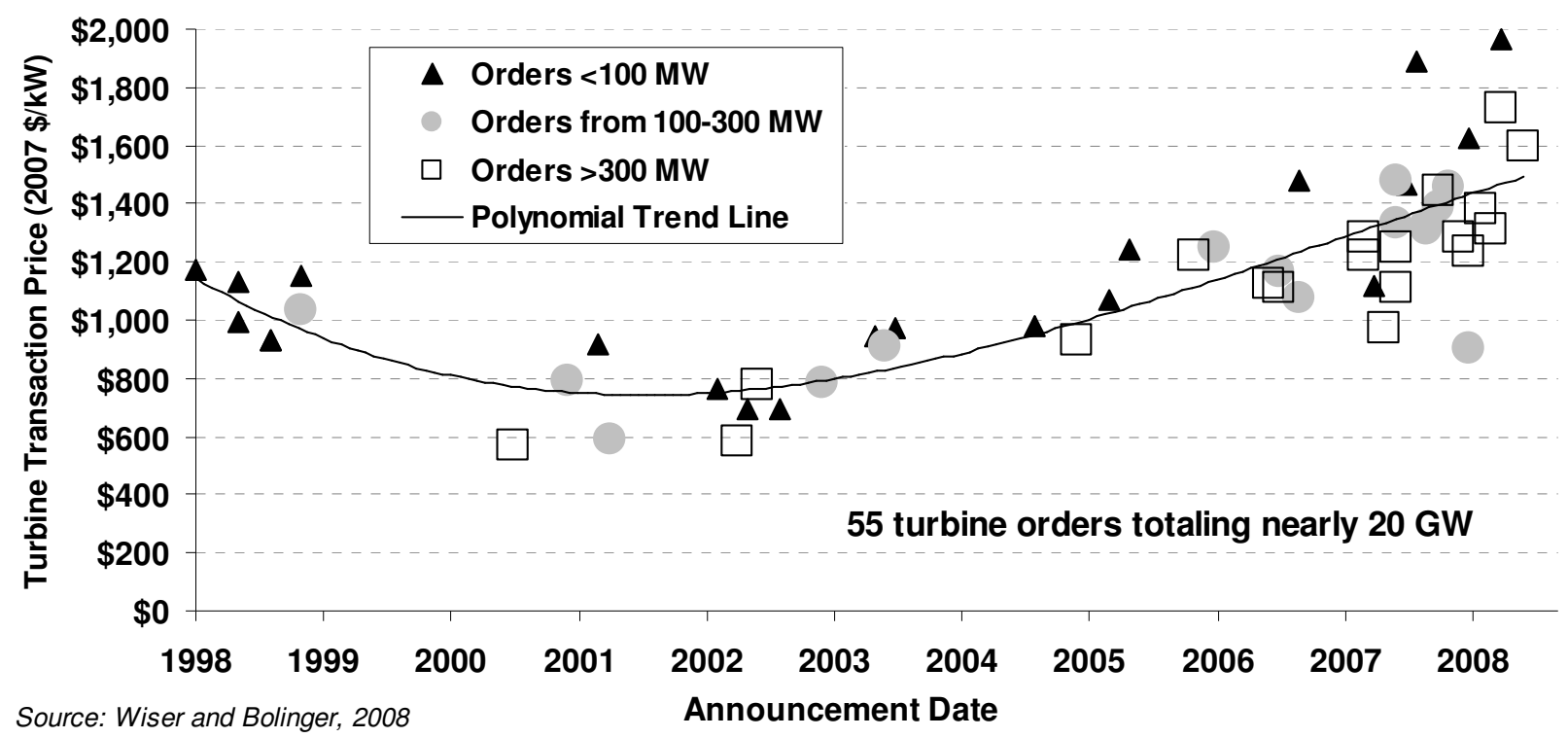

\section{Figure 7. Reported U.S. Wind Turbine Transaction Prices Over Time}

\subsection{Installed Project Costs}

With turbines accounting for $75-80 \%$ of total wind project costs, higher turbine prices have unavoidably led to higher installed project costs. Berkeley Lab has compiled a sizable database of the estimated installed costs of wind projects in the United States. In aggregate, the dataset includes 227 wind projects totaling nearly $13 \mathrm{GW}$ installed in the continental United States through 2007 (i.e., 77\% of all U.S. wind capacity built through 2007). Unavailability of data, particularly among older projects, prevents a more-complete sample; for example, nearly 12.5 GW of our $13 \mathrm{GW}$ sample were built from 1998 through 2007 (our sample of projects built over just this decade represents $82 \%$ of total U.S. wind capacity installed during this period). ${ }^{8}$ The dataset also includes cost projections for a sample of 26 projects totaling $2.8 \mathrm{GW}$ that are expected to be completed in 2008. In general, reported project costs reflect turbine purchase and installation, balance of plant, and any substation and/or interconnection expenses. Data sources

agreement, etc.) and on the timing of future turbine delivery, driving some of the observed intra-year variability in transaction prices, and complicating price comparisons. Nonetheless, most of the transactions included in the Berkeley Lab dataset likely include turbines, towers, erection, and limited warranty and service agreements, and movements in the average prices over time are reasonable characterization of price trends.

${ }^{8}$ Criteria for inclusion in the database are quite simple: if reasonably credible installed cost data (from either public or confidential sources) can be found for a project, then that project is included in the installed cost database (pending receipt of permission from any confidential sources). As such, if any sampling bias exists, it is likely to involve a primary focus on more-recent projects, since credible data on older projects is harder to find. Given that we are primarily interested in cost trends among more-recent projects, however, any such sampling bias that may exist is of limited concern. 
are diverse, however, and are not all of equal credibility, ${ }^{9}$ so emphasis should be placed on overall trends in the data, rather than on individual project-level estimates.

As shown in Figure 8, wind project installed costs declined dramatically from the beginnings of the industry in California in the 1980 s to the early 2000 s, falling by roughly $\$ 2,700 / \mathrm{kW}$ over this period. ${ }^{10}$ At their lowest point (i.e., in the 2001-2004 time period), project costs averaged roughly $\$ 1,250 / \mathrm{kW}$ (in constant 2007 dollars). More recently, however, costs have increased. Among the sample of projects built in 2007, reported installed costs ranged from $\$ 1,240 / \mathrm{kW}$ to $\$ 2,600 / \mathrm{kW}$, with a capacity-weighted average cost of $\$ 1,690 / \mathrm{kW}$. This is $\$ 155 / \mathrm{kW}(10 \%)$ higher than the weighted-average cost of installed projects in $2006(\$ 1,535 / \mathrm{kW})$, and is roughly $\$ 440 / \mathrm{kW}(35 \%)$ higher than the weighted-average cost of projects installed in the 2001-2004 time frame. Project costs in 2008 have risen even more sharply, with a capacity-weighted average of $\$ 2,025 / \mathrm{kW}$, or $\$ 335 / \mathrm{kW}(20 \%)$ higher than seen in 2007 . Overall, since the 20012004 period, average project costs in 2008 have increased by $\$ 775 / \mathrm{kW}$, or $62 \%$, returning to levels not seen since the early 1990 s.

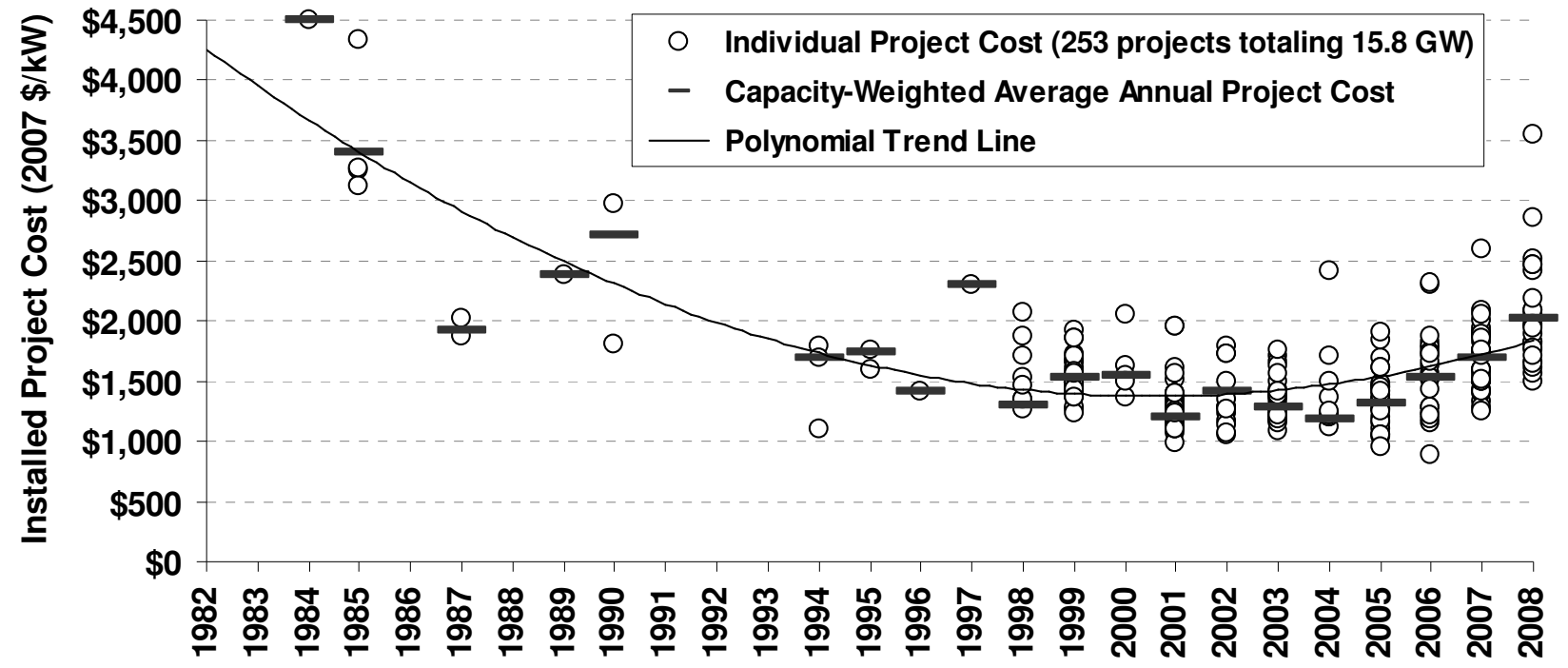
Source: Wiser and Bolinger, 2008

\section{Figure 8. Installed Wind Project Costs Over Time}

\subsection{Wind Power Prices}

Higher installed project costs must eventually be recovered through higher wind power sales prices. Berkeley Lab maintains a database of wind power sales prices, which currently contains

\footnotetext{
${ }^{9}$ Data sources include news stories, press releases, state and federal regulatory filings, government databases, detailed case studies, personal communication, and other research reports. Each project cost estimate is ranked based on the quality of the source, using the following scale: press releases (or similar) before the project is built are assigned a 1; press releases (or similar) after the project is built are assigned a 2; more-detailed analyses of likely costs prior to construction are assigned a 3; more-detailed analyses of likely costs after construction are assigned a 4; and verified post-construction costs are assigned a 5. Among the 227 projects in our sample that were built through the end of 2007, the average quality ranking was 3.2, with a standard deviation of 1.3. Projects ranked as either a 4 or a 5 totaled 127 of the 227 projects (56\%), and roughly $6 \mathrm{GW}$ out of the total $13 \mathrm{GW}(46 \%)$.

${ }^{10}$ Limited sample size early on - particularly in the $1980 \mathrm{~s}$ - makes it difficult to pin down this number with a high degree of confidence.
} 
price data for 128 projects installed between 1998 and the end of 2007 . These wind projects total $8,303 \mathrm{MW}$, or $55 \%$ of the wind capacity brought on line in the U.S. over the 1998-2007 period. ${ }^{11}$ The prices in this database reflect the price of electricity as sold by the project owner, and might typically be considered busbar energy prices. ${ }^{12}$ The prices are suppressed by the receipt of any available state and federal incentives (e.g., the PTC, shown earlier to be worth roughly \$20/MWh of pre-tax revenue on a levelized basis), as well as by the value that might be received through the separate sale of renewable energy certificates (RECs). ${ }^{13}$ The prices reported here would therefore be higher if wind projects did not have access to these state and federal incentives, and, as a result, these prices do not represent the cost of wind generation.

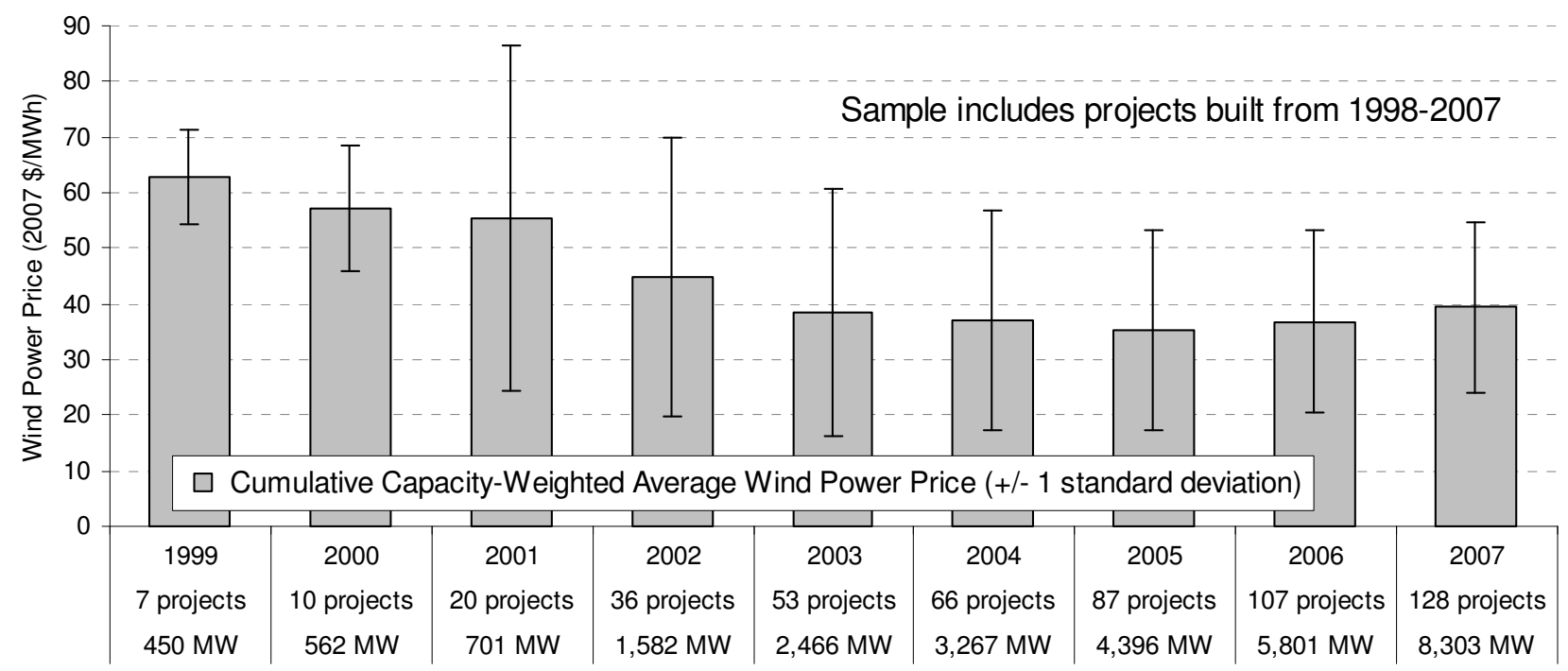

Source: Wiser and Bolinger, 2008

\section{Figure 9. Cumulative Capacity-Weighted Average Wind Power Prices Over Time}

Based on this database, the capacity-weighted average power sales price from the sample of post-1997 wind projects remains low by historical standards. Figure 9 shows the cumulative capacity-weighted average wind power price (plus or minus one standard deviation around that price) in each calendar year from 1999 through 2007. As shown, based on the limited sample of

\footnotetext{
${ }^{11}$ Sample size is limited only by data availability. For example, projects located in the portion of Texas served by the Electric Reliability Council of Texas (ERCOT) do not fall under the jurisdiction of the Federal Energy Regulatory Commission (FERC), and therefore are not required to file transaction-related information with the FERC. Hence, our sample includes only a limited number of Texas projects (primarily those projects that are part of the Southwestern Power Pool, rather than ERCOT), even though Texas has by far the most installed wind capacity of any state in the U.S. Furthermore, an increasing number of wind projects in the United States are owned by utilities, which sell the wind power directly to their retail customers as part of the overall power mix, rather than selling it on a wholesale basis with a uniquely observable price.

${ }^{12}$ These prices will typically include interconnection costs and, in some cases, limited transmission expansion costs that are needed to ensure delivery of the energy to the power purchaser.

${ }^{13}$ For most of the wind power sales prices reported here, the wind generator is selling electricity and RECs in a bundled fashion, and the price reported here therefore reflects the delivery of that bundled product. For at least 10 of the 128 projects in the sample, however, the wind project appears to receive additional revenue (beyond the power price reported) from the separate sale of RECs. The prices presented in this article do not include this separate REC revenue stream, and therefore understate total sales revenue for these 10 projects. Because only a small minority of projects fall into this category, however, the omission of REC revenue is unlikely to significantly bias downward the overall trends presented.
} 
7 projects built in 1998 or 1999 and totaling $450 \mathrm{MW}$, the weighted-average price of wind in 1999 was nearly \$63/MWh (expressed in 2007 dollars). By 2007, in contrast, the cumulative sample of projects built from 1998 through 2007 had grown to 128 projects totaling 8,303 MW, with an average price of just under $\$ 40 / \mathrm{MWh}$ (with the one standard deviation range extending from $\$ 24 / \mathrm{MWh}$ to $\$ 55 / \mathrm{MWh}$ ). Although Figure 9 does show a modest increase in the weightedaverage wind power price in 2006 and 2007, reflecting rising prices from newer projects, the cumulative nature of the graphic mutes the degree and distorts the timing of the increase.

For a more-responsive and more-appropriate indicator of wind power price movements, Figure 10 shows changes in power sales prices from newly built wind projects over time. Specifically, Figure 10 shows average wind power sales prices in the year 2007, parsed by the year in which each project was built. Although the limited project sample and the considerable variability in prices across projects installed in a given time period complicate analysis of national price trends (with averages subject to regional and other factors, such as economies of scale from larger projects), the general trend exhibited by the capacity-weighted-average prices (i.e., the shaded columns) nevertheless suggests that, following a general decline since 1998 (and presumably extending back in time earlier than 1998), prices bottomed out for projects built in 2002 and 2003 , and have since risen significantly among more newly built projects. ${ }^{14}$

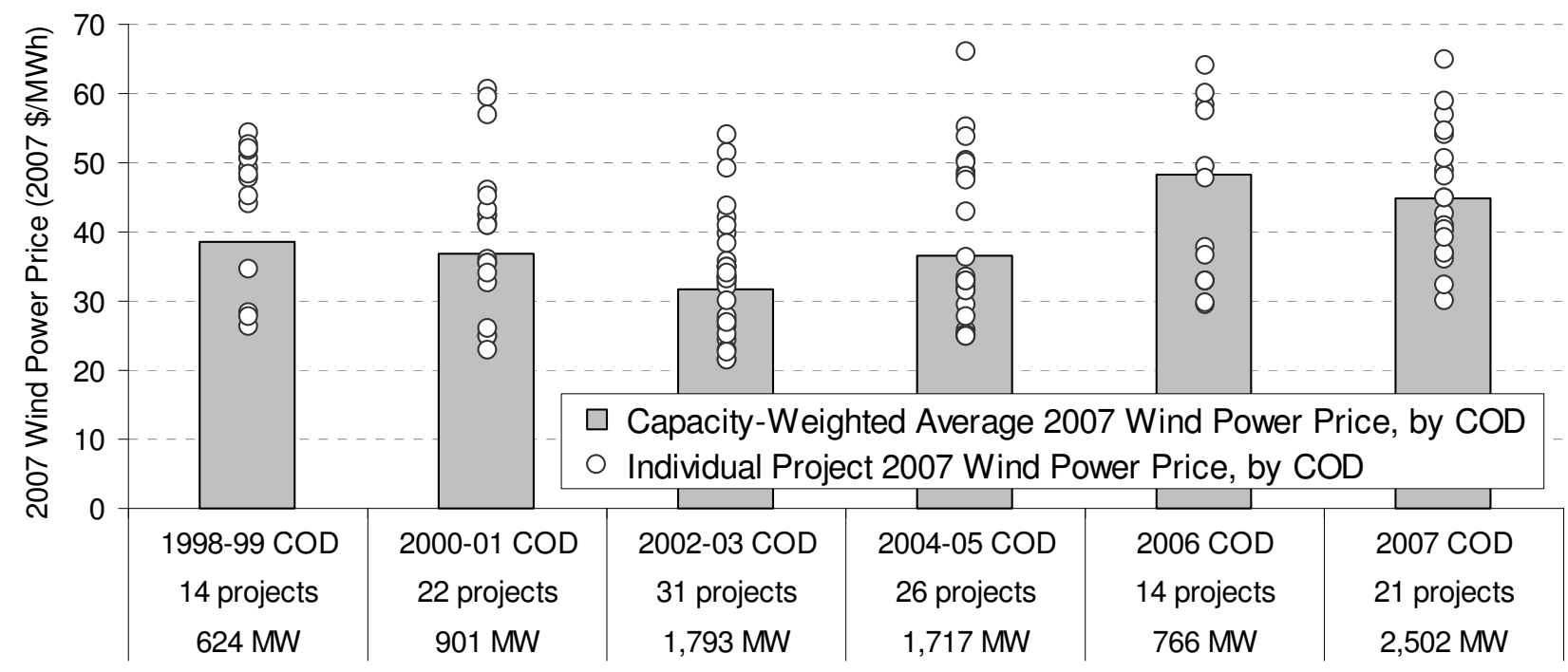

Source: Wiser and Bolinger, 2008

Figure 10. 2007 Wind Power Prices by Commercial Operation Date (COD)

\footnotetext{
${ }^{14}$ Although it may seem counterintuitive, the weighted-average price in 1999 for projects built in 1998 and 1999 (shown in Figure 9 to be about \$63/MWh) is significantly higher than the weighted-average price in 2007 for projects built in 1998 and 1999 (shown in Figure 10 to be \$39/MWh) for three reasons: (1) the sample size is larger in Figure 10, due to the fact that 2007 prices are presented, rather than 1999 prices as in Figure 9 (i.e., we were unable to obtain early-year pricing for some of the projects built in 1998-1999); (2) two of the larger projects built in 1998 and 1999 (for which both 1999 and 2007 prices are available, meaning that these projects are represented within both figures) have nominal power purchase agreement (PPA) prices that actually decline, rather than remaining flat or escalating, over time; and (3) inflating all prices to constant 2007 dollar terms impacts older (i.e., 1999) prices more than it does more recent (i.e., 2007) prices. Survivorship bias is not an issue in either figure, as no wind projects built during this period have failed.
} 
Specifically, the capacity-weighted average 2007 sales price for projects in the sample built in 2007 was roughly $\$ 45 / \mathrm{MWh}$ (with a range of $\$ 30$ to $\$ 65 / \mathrm{MWh}$ ). ${ }^{15}$ Although this price is (somewhat surprisingly) slightly less than the average of $\$ 48 / \mathrm{MWh}$ for the sample of projects built in 2006, it is still higher than the average price of $\$ 37 / \mathrm{MWh}$ for the sample of projects built in 2004 and 2005, as well as the \$32/MWh for the sample of projects built in 2002 and 2003. Moreover, because ongoing turbine price increases are not fully reflected in 2007 wind project costs or power prices (many of these projects had locked in turbine prices and/or negotiated power purchase agreements as much as 18 to 24 months prior to the start of commercial operations), wind power prices from projects being built in 2008 and beyond are likely to be higher still.

\subsection{Looking Ahead}

To provide a sense of where installed project costs, and hence wind power prices, might be headed in the near future, Figure 11 combines the turbine price data and installed project cost data from Figures 7 and 8, respectively, into a single graphic. In Figure 11, however, the turbine price data are shifted forward by 12 months, to account for a typical period between when turbines are ordered (i.e., when the transaction is priced and announced) and when they are ultimately delivered and installed (i.e., when installed project costs are finalized). With this shift, the shape of the polynomial trend lines between the two datasets matches up reasonably well, suggesting - based solely on the price of current turbine orders - that the installed cost of wind projects built in 2009 could rise to $\$ 2,250 / \mathrm{kW}$ on average, from around $\$ 2,000 / \mathrm{kW}$ for projects achieving commercial operations in 2008.

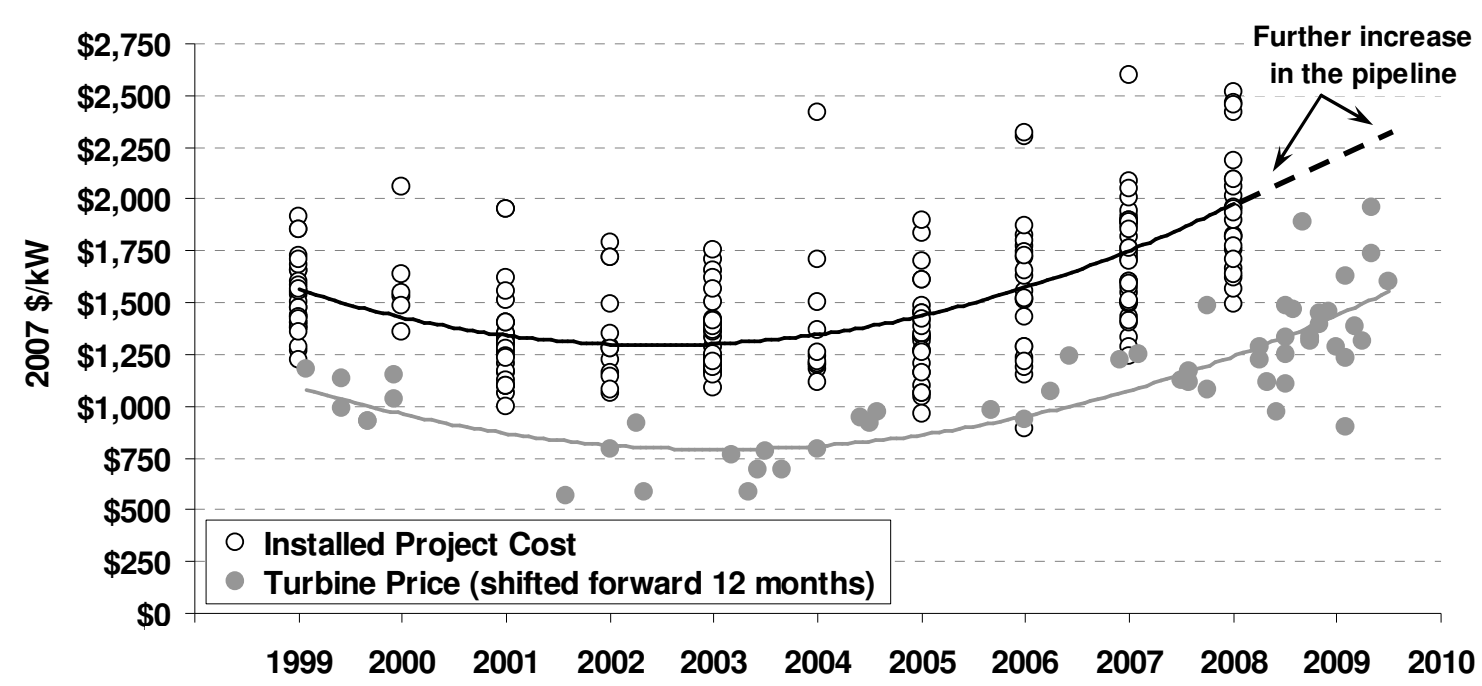

Figure 11. Projecting Future Installed Project Costs From Current Wind Turbine Orders

Higher installed costs for projects built in 2008 and 2009 can be expected, in turn, to push wind power prices above the levels shown in Figures 9 and 10 (neither of which extends beyond 2007vintage projects). For example, inserting average installed costs of $\$ 2,000 / \mathrm{kW}$ in 2008 and

\footnotetext{
${ }^{15}$ If the federal PTC was not available, wind power prices for 2007 projects would range from approximately $\$ 50 / \mathrm{MWh}$ to $\$ 85 / \mathrm{MWh}$, with an average of roughly $\$ 65 / \mathrm{MWh}$.
} 
$\$ 2,250 / \mathrm{kW}$ in 2009 into the pro forma financial model described in Harper et al. (2007) reveals that, all else equal (including ongoing PTC availability), wind power prices could rise to an average of around \$70/MWh for projects built in 2008 and \$80/MWh for projects built in 2009 .

\subsection{The Mitigating Influences of Finance and Project Performance}

Though higher turbine and installed project costs have driven wind power prices higher in recent years, improvements in financing terms and wind project performance over this same time period have relieved some of the pressure, enabling wind prices to rise more gradually than they otherwise would have. Whether and to what degree either of these two mitigating factors can continue to cushion the blow going forward remains to be seen.

\subsection{Financing Terms}

Wind projects are capital-intensive to construct and, as a result, financing terms can have a major influence on the cost (and price) of energy delivered from a wind project. The $12.2 \mathrm{GW}$ of new wind capacity added in the United States from 2003-2007 has required an investment of roughly $\$ 18.5$ billion (in constant 2007 dollars), with $\$ 9$ billion required in 2007 alone. Fortunately, over this period, the wind industry's growing need for capital has been met with enthusiasm from several different types of investors, but most notably institutional tax equity investors (i.e., large banks, insurance companies, and other institutions that invest in wind projects primarily to reduce their income tax liability).

Institutional tax equity investors are primarily comprised of large banks and insurance companies that invest in U.S. wind projects mainly for the tax benefits they provide (i.e., the production tax credit and deductions for accelerated tax depreciation). With yields from other competing taxbased investments declining to relatively unattractive levels in recent years, institutional tax investors have turned to the U.S. wind market in earnest since roughly 2003. JP Morgan, one of the largest tax investors active in the U.S. wind market, estimates the growth of tax equity financing for wind in the U.S. as rising from 13 transactions from 2003-2005, to 15 transactions totaling $\$ 3.1$ billion in 2006, 18 transactions totaling $\$ 5.2$ billion in 2007, and 25 transactions totaling $\$ 8$ billion expected in 2008 (Harper et al., 2007; Eber, 2008).

This flood of tax equity into the wind industry, coupled with increasing competition among tax equity providers, has driven down the cost of tax equity. Specifically, Harper et al. (2007) estimate that the cost of tax equity provided to high-quality wind projects in the U.S. has declined by roughly 300 basis points (3\%) over the period from 2003-2007. Using the pro forma financial model described in Harper et al. (2007), Bolinger (2008) estimates that this reduction in the cost of equity has, all else equal, enabled wind project owners to charge about \$12/MWh less than they would have otherwise had to in order to meet investor return targets.

Looking ahead, it is unlikely that financing terms will continue to improve as they have in the recent past. For starters, at $7 \%$ or less for transactions that do not involve debt, tax equity yields have fallen to what many consider to be unsustainably low levels (e.g., rivaling the cost of debt, despite the added risk). Furthermore, the global credit crisis has hit banks and other tax investors 
hard, leaving them with fewer profits to shelter, and therefore less tax equity to invest. At the same time, rising yields in other tax-based investments (e.g., yields on low-income housing credits have reportedly jumped as two of the largest buyers of such credits have essentially pulled out of the market due to financial difficulties), as well as emerging investment opportunities in other renewable energy sectors (e.g., solar and geothermal), will create competition for tax equity that is currently directed towards the wind sector. As a result of these factors, finance is unlikely to continue to mitigate - and more likely will exacerbate, given that the global credit crisis is already pushing debt and tax equity yields higher - the impact of future cost pressures on wind power prices.

\subsection{Capacity Factors}

As with financing terms, improvements in project performance have also helped to relieve some of the upward pressure on wind power prices in recent years. Berkeley Lab has compiled a database of wind project capacity factor data, consisting of 170 projects built between 1983 and 2006 , and totaling $10,564 \mathrm{MW}$ (91\% of nationwide installed wind capacity at the end of 2006). ${ }^{16}$ Though capacity factors are not an ideal metric of project performance (due to variations in the design and rating of wind turbines), they are nevertheless a useful and commonly used performance indicator.

Figure 12 shows individual project as well as capacity-weighted average 2007 capacity factors broken out by the year in which each project achieved commercial operation. ${ }^{17}$ The capacityweighted average 2007 capacity factors in the Berkeley Lab sample increased from $22 \%$ for wind projects installed before 1998 to roughly 30\%-32\% for projects installed from 1998-2003, and to roughly $33 \%-35 \%$ for projects installed from $2004-2006{ }^{18}$

Furthermore, in the best wind resource areas, capacity factors in excess of $40 \%$ are increasingly common. Of the 112 projects in the sample installed prior to 2004, for example, only four (3.6\%) had capacity factors in excess of $40 \%$ in 2007 (in capacity terms, $56 \mathrm{MW}$, or $1 \%$, exceeded 40\%). Of the 58 projects installed from 2004 through 2006, on the other hand, fifteen $(25.9 \%$ ) achieved capacity factors in excess of $40 \%$ in 2007 (in capacity terms, $836 \mathrm{MW}$, or $16.7 \%$, exceeded $40 \%$ ).

\footnotetext{
${ }^{16}$ The dataset does not include projects installed in 2007 because we focus on full-year 2007 performance. Our $91 \%$ sample size is more complete than it was for installed costs or wind power prices due solely to differences in data sources: much of the capacity factor data comes from the Energy Information Administration, which attempts to collect performance data from all, rather than just a subset, of power projects. That said, some of the performance data from a few of the oldest wind projects installed during the 1980s appear to be suspect (e.g., some of these projects are no longer operating at their original installed capacity), and are therefore excluded from our sample.

${ }^{17}$ Focusing on capacity factors in just the year 2007 removes the potential impact of inter-annual fluctuations in the nationwide wind resource. On the other hand, focusing just on 2007 means that the absolute capacity factors shown may not be representative if 2007 was not a representative year in terms of the strength of the wind resource.

${ }^{18}$ The capacity-weighted-average 2007 capacity factor for projects installed in $2006(33.4 \%)$ is down slightly from that for projects installed in 2004-2005 (34.8\%), in large part due to the impact of a single large project.

Specifically, a very large 2006 project in Texas achieved a capacity factor of just $28.7 \%$ in 2007 ; if this single project were excluded from the sample, the capacity-weighted-average 2007 capacity factor from projects built in 2006 would rise to $35.7 \%$ (up from $34.8 \%$ for projects built in 2004-2005).
} 


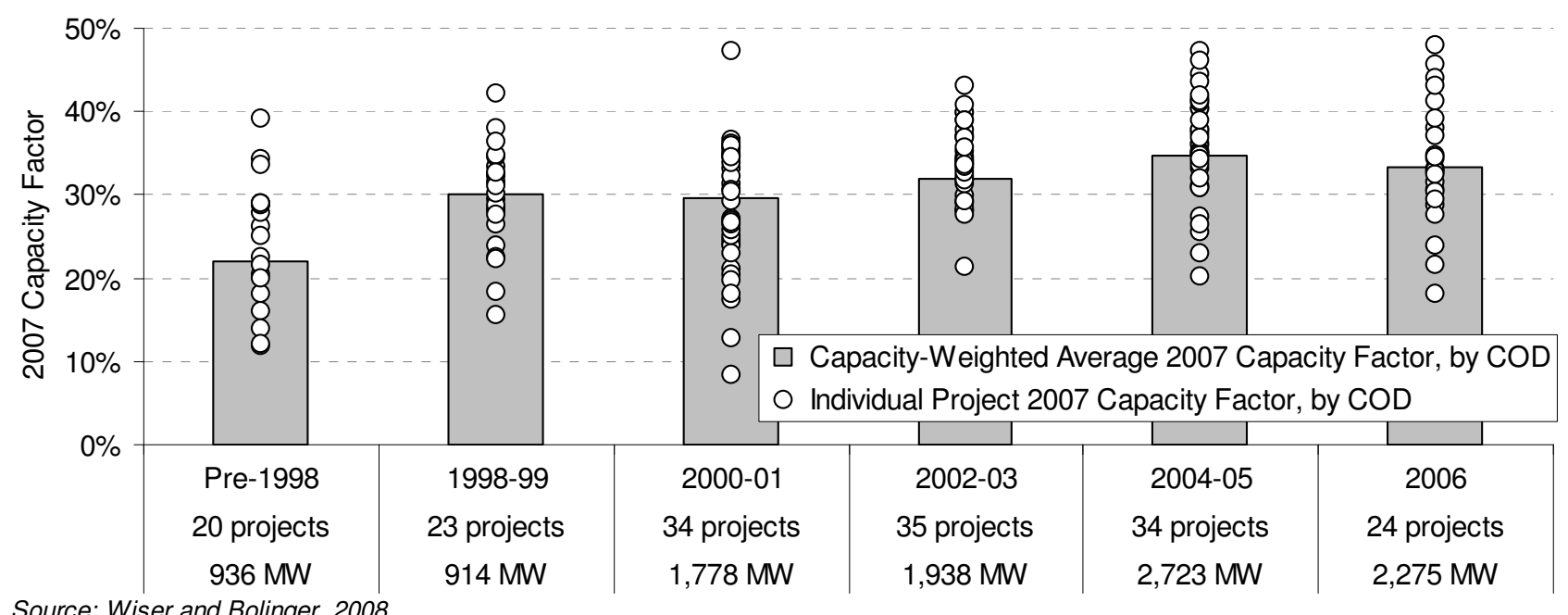

Figure 12. 2007 Project Capacity Factors by Commercial Operation Date

This increase in capacity factor among more recently built projects suggests that moresophisticated turbine designs, higher hub heights, and/or improved project and turbine siting are outweighing the otherwise-presumed trend towards lower-value wind resource sites as the best locations are developed. However, further analysis would be needed to determine the relative importance of the variables influencing performance improvements. ${ }^{19}$

Once again turning to the pro forma financial model described in Harper et al. (2007), Bolinger (2008) estimates that a modest improvement in capacity factor from $32 \%$ to $35 \%$ - i.e., roughly on the order of that shown in Figure 12 over the past few years - will, all else equal, allow project owners to shave an additional $\$ 9 / \mathrm{MWh}$ off the price they must charge. In combination with the $\$ 12 / \mathrm{MWh}$ financing benefit discussed above, this $\$ 9 / \mathrm{MWh}$ capacity factor benefit means that wind power prices would, on average, be roughly $\$ 21 / \mathrm{MWh}$ higher than shown in Figure 10 had neither of these two mitigating factors come to pass.

\subsection{Despite Cost Pressures, Wind Remains Competitive in Wholesale Power Markets}

Notwithstanding the mitigating influences of financing terms and project performance, wind prices have risen in recent years and, as described earlier, are expected to continue their upward trend in the near term. At the same time, it is important to recognize that wind is not alone in facing upward pressure on project costs - other types of power plants have seen similar increases in capital costs in recent years.

In September 2007, for example, the Edison Foundation published a report showing increases in the installed cost of both natural gas and coal power plants in the United States that rival that seen in the wind industry (Chupka and Basheda, 2007). More recently, IHS and Cambridge

\footnotetext{
${ }^{19}$ Although the overall trend is towards higher capacity factors, the project-level spread shown in Figure 12 is enormous, with capacity factors ranging from $18 \%$ to $48 \%$ among projects built in the same year, 2006. As shown in Wiser and Bolinger (2008), some of this spread is attributable to regional variations in wind resource quality.
} 
Energy Research Associates have updated their Power Capital Costs Index, which tracks the costs of building coal, gas, wind, and nuclear power plants in North America since 2000.

Through the first quarter of 2008, the combined index showed a $131 \%$ increase in the cost of building a portfolio of these four resources since 2000. Excluding nuclear, the remaining index was up $82 \%$ since 2000 , with wind rising $108 \%$ in nominal dollar terms (roughly consistent with the turbine and project cost data shown in Figures 7 and 8), gas rising 92\%, and coal up 78\% over this period (IHS CERA, 2008). Finally, rising fuel prices (gas, coal, uranium) have increased the operating costs of non-wind power plants - a fact that is not considered by either of the two studies referenced above.

As a result, despite rising costs, wind's competitive position has not changed as dramatically in recent years as might otherwise be expected. This fact can be seen in a simple comparison of wind power prices to recent wholesale power prices throughout the United States. The shaded area in Figure 13 shows the range (minimum and maximum) of average annual wholesale power prices for a flat block of power ${ }^{20}$ going back to 2003 at twenty-three different pricing nodes located throughout the United States. The black circles show the cumulative capacity-weighted average price received by wind projects in each year among those projects in the sample with commercial operation dates of 1998 through 2007 (consistent with the data presented earlier in Figure 9). At least on a cumulative basis within the sample of projects reported here, average wind power prices have consistently been at or below the low end of the wholesale power price range over this period.

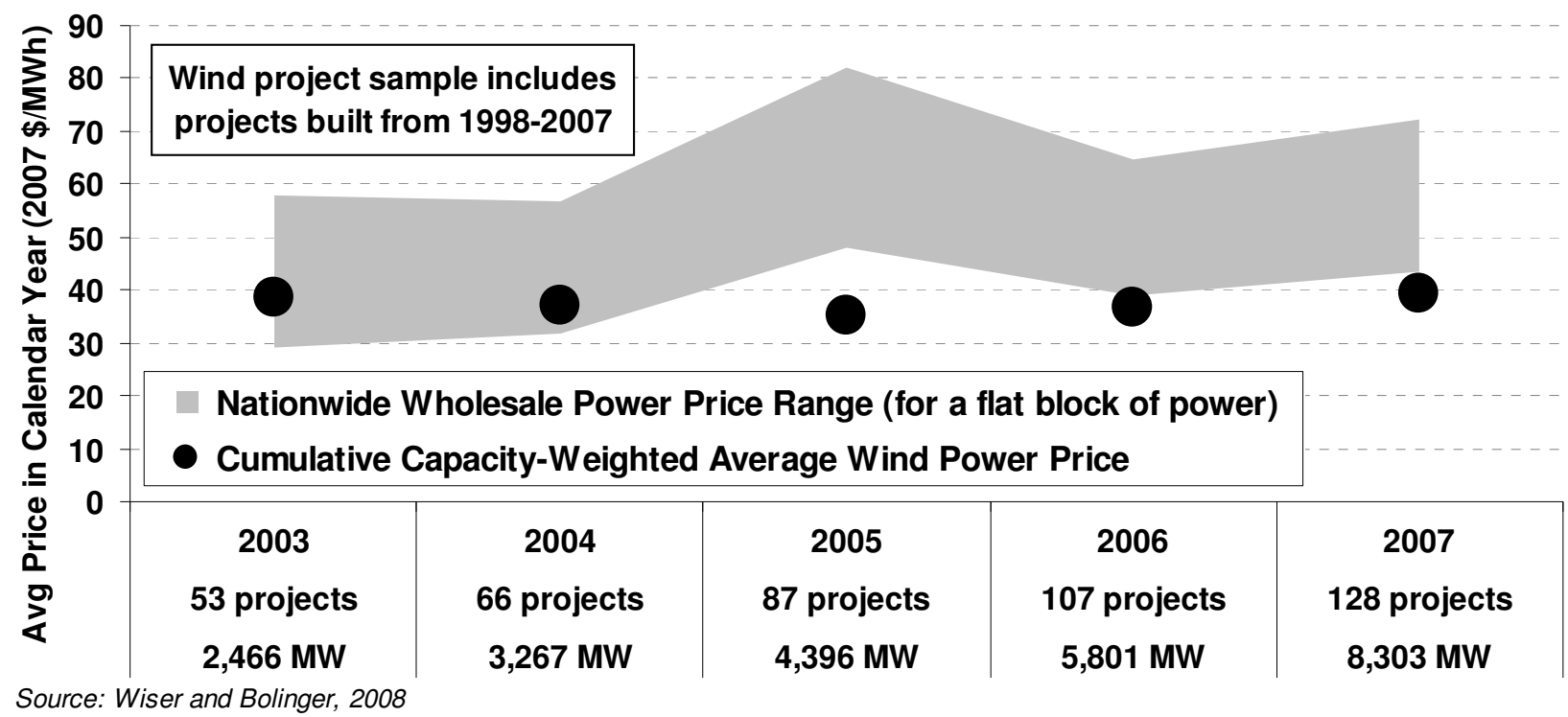

Figure 13. Average Cumulative Wind and Wholesale Power Prices Over Time

\footnotetext{
${ }^{20}$ Though wind projects do not provide a perfectly flat block of power, as a common point of comparison, a flat block is not an unreasonable starting point (see, e.g., Fripp and Wiser, 2008). In other words, the time-variability of wind generation is often such that its wholesale market value is somewhat lower than, but not too dissimilar from, that of a flat block of (non-firm) power.
} 
Although the comparison is admittedly simplistic, ${ }^{21}$ Figure 13 demonstrates that, with the PTC, wind has been competitive with other forms of generation in recent years - a realization that has driven significant wind power capacity growth over this period. As noted earlier, however, wind power prices from projects built in 2008 and 2009 may need to rise to $\$ 70-\$ 80 / \mathrm{MWh}$, respectively, in order to recover higher installed project costs. Incorporating the higher tax equity yields currently seen in the market would drive these required prices even higher. Whether wind power at these higher price levels can remain competitive with other forms of generation remains to be seen.

\subsection{Conclusions}

The amount of wind power capacity being installed globally is surging, with the United States currently the world leader in terms of annual market share. Strong growth has been a doubleedged sword, however, as the resulting supply-demand imbalance in available wind turbines and components has led to a sellers' market, with associated turbine price increases. Furthermore, this supply-demand imbalance has come at a time when the cost of manufacturing wind turbines has increased due to higher commodity (materials and energy) prices, and the purchasing power of U.S.-based turbine buyers has declined due to weakness in the dollar. ${ }^{22}$

These cost pressures have driven wind power prices higher in the U.S., though not yet to the point where wind has become uncompetitive or demand destruction has become a significant problem. Two mitigating factors - reductions in the cost of equity provided to wind projects and improvement in project-level capacity factors - have helped to relieve some of the upward pressure on wind power prices over the last few years. To what degree these two mitigating factors can continue to cushion the blow going forward remains to be seen, but appears somewhat questionable, particularly in the case of tax equity yields, which have already reversed course and are rising in response to global financial turmoil.

The increasing cost and price trends demonstrated in this article are obviously of great relevance to wind industry participants, both in the United States and worldwide. In addition, these trends hold equally important implications for forecasters and for policymakers.

Specifically, the data presented here clearly suggest that those forecasting future wind power costs and prices should benchmark the early years of those forecasts to current market

\footnotetext{
${ }^{21}$ It should be recognized that neither the wind nor wholesale power prices presented in Figure 13 reflect the full social costs of power generation and delivery. Specifically, the wind power prices are suppressed by virtue of federal and, in some cases, state tax and financial incentives (a few projects also receive additional revenue from unbundled REC sales). Furthermore, these prices do not fully reflect integration, resource adequacy, or transmission costs. At the same time, wholesale power prices do not fully reflect transmission costs, may not fully reflect capital and fixed operating costs, and are suppressed by virtue of any financial incentives provided to fossil-fueled generation and by not fully accounting for the environmental and social costs of that generation. In addition, wind power prices - once established - are typically fixed and known, whereas wholesale power prices are short-term and therefore subject to change over time. Finally, the location of the wholesale pricing nodes and the assumption of a flat-block of power are not perfectly consistent with the location and output profile of the sample of wind projects.

${ }^{22}$ Berkeley Lab will be exploring the relative influence of these cost drivers in an upcoming report. Preliminary analysis suggests that dollar weakness has had the largest impact among those drivers mentioned here (Bolinger, 2008).
} 
conditions, rather than using outdated installed cost data, for example. Similarly, forecasts of deep wind cost reductions in the medium- to longer-term may need to be revisited, or at least justified, in light of current technology and trends. Moreover, just as it is common to consider uncertainty in the cost of fossil generation when constructing forecasts, recent trends in wind power costs also suggest that uncertainty bounds should be placed on any projection of future wind costs and prices. Finally, the results presented here also caution against over-use of and/or over-confidence in the learning curve model as the sole determinant of future wind power costs. $^{23}$ At least in the United States, installed wind project costs in 2008 are likely to be on par with those seen in the early 1990s, and while there is an expectation for continued cost reductions in the medium- to longer-term, few expect project-level installed costs to drop to the level already achieved in the early 2000s (see, e.g., U.S. Department of Energy, 2008).

For policymakers intent on stimulating the continued growth of wind power, the data presented in this article further confirm that policy needs to remain both vigilant and nimble. The fact that the amount of new wind capacity has been growing rapidly does not necessarily mean that wind no longer requires policy support. On the contrary, increasing cost and pricing trends, in combination with exogenous financial shocks that hit capital-intensive technologies like wind power particularly hard, may in some cases require an increase in both the level and duration of policy support if continued growth is desired. Germany, for example, has recently increased its feed-in tariff for wind in response to the higher costs facing the sector.

Moreover, it is inescapable that some of the upward cost and price pressure troubling the wind sector is due to the rapid and, to some degree, unexpected growth of that industry in recent years, which itself has been affected by the scale and unpredictability of policy support (Wiser et al., 2007). To regain the desired path of steady cost and price reductions, longer-term policy stability may be required to ensure that the massive upscaling underway in the wind industry is conducted in a sustainable and efficient, rather than chaotic, manner. Though welcomed by the industry as a stop-gap measure, the single-year extension of the PTC (through 2009) enacted in October 2008 is arguably too short-term in nature to help much in this regard.

Finally, the recent financial turmoil that has rocked equity and credit markets throughout the world highlights the risk of using tax policy as a means of stimulating an emerging industry. The tax-intensive nature of the PTC has led to a highly specialized form of wind project finance in the United States (Harper et al., 2007), one that is overly reliant on large financial institutions providing passive tax equity. With many of these institutions now in dire trouble (and some defunct), there is a noticeable shortage of tax equity available to sustain the growth of wind power in the U.S. A different type of policy support mechanism that more-easily enables broader equity participation from multiple types of equity providers (e.g., private equity funds, corporate equity, sponsor equity, individual investor equity), would arguably have helped to limit the impact of the unfolding credit crisis on the U.S. wind power market.

\footnotetext{
${ }^{23}$ A sizable literature has developed on the use of learning curves to explain historical and forecast future wind cost and pricing trends (see, e.g., Ibenholt, 2002; IEA, 2000; Junginger et al., 2005; Kobos et al., 2006; McDonald and Schrattenholzer, 2001; Neij, 1997; Neij, 2008). Most of this literature uses data-sets that do not contain the recent run-up in wind power costs and pricing. Moreover, in recent years, some have questioned the applicability of learning effects to renewable energy technologies (Nemet, 2006; Papineau, 2006).
} 


\section{References}

Barbose, Galen, Ryan Wiser, Amol Phadke, Charles Goldman. 2008. Reading the Tea Leaves: How Utilities in the West Are Managing Carbon Regulatory Risk in their Resource Plans. LBNL-44E. Berkeley, Calif.: Lawrence Berkeley National Laboratory. http://eetd.lbl.gov/ea/ems/reports/lbnl-44e.pdf (last accessed June 20, 2008)

Bird, Lori, Leila Dagher, Blair Swezey. 2007. Green Power Marketing in the United States: A Status Report (10 ${ }^{\text {th }}$ Edition). NREL/TP-670-42502. Golden, Colorado: National Renewable Energy Laboratory. http://www.eere.energy.gov/greenpower/resources/pdfs/42502.pdf (last accessed June 20, 2008)

Bird, Lori, Mark Bolinger, Troy Gagliano, Ryan Wiser, Matthew Brown, and Brian Parsons. 2005. "Policies and Market Factors Driving Wind Power Development in the United States" Energy Policy. Vol 33, Issue 11, July 2005, pp. 1397-1407.

Bolinger, Mark. 2008. "Trends in U.S. Wind Power Prices and the Factors that Influence Them." WINDPOWER 2008 conference presentation, Houston, Texas, June 2, 2008.

Bolinger, Mark and Ryan Wiser. 2005. Balancing Cost and Risk: The Treatment of Renewable Energy in Western Utility Resource Plans. LBNL-58450. Berkeley, Calif.: Lawrence Berkeley National Laboratory. http://eetd.lbl.gov/ea/ems/reports/58450.pdf (last accessed June 20, 2008)

BTM Consult. 2008. "International Wind Energy Development: World Market Update 2007." Ringkobing, Denmark: BTM Consult.

Byrne., J., K. Hughes, W. Rickerson and L. Kurdgelashili. 2007. "American Policy Conflict in the Greenhouse: Divergent Trends in Federal, Regional, State and Local Green Energy and Climate Change Policy." Energy Policy, 35: 4555-4573.

Chupka, Marc and Gregory Basheda. 2007. Rising Utility Construction Costs: Sources and Impacts. Prepared by The Brattle Group for The Edison Foundation, September 2007. http://www.edisonfoundation.net/Rising_Utility_Construction_Costs.pdf (last accessed June 20, 2008)

Eber, John. 2008. Remarks made during the "Financing Options and Structures" panel discussion at WINDPOWER 2008. Houston, Texas, June 2, 2008.

European Wind Energy Association (EWEA). 2008. "Pure Power: Wind Energy Scenarios up to 2030.” Brussels, Belgium: European Wind Energy Association.

Fripp, M. and R. Wiser. 2008. "Effects of Temporal Wind Patterns on the Value of WindGenerated Electricity in California and the Northwest." IEEE Transactions on Power Systems, 23 (2): 477-485. 
Global Wind Energy Council (GWEC). 2008. "Global Wind 2007 Report.” Brussels, Belgium: Global Wind Energy Council.

Harper, John, Matt Karcher, Mark Bolinger. 2007. Wind Project Financing Structures: A Review \& Comparative Analysis. LBNL-63434. Berkeley, Calif.: Lawrence Berkeley National Laboratory. http://eetd.lbl.gov/ea/ems/reports/63434.pdf (last accessed June 20, 2008)

Ibenholt, K. 2002. “Explaining Learning Curves for Wind Power.” Energy Policy, 30: 11811189.

IHS CERA. 2008. "Construction Costs for New Power Plants Continue to Escalate: IHS CERA Power Capital Costs Index." May 27, 2008 press release, available at http://energy.ihs.com/News/Press-Releases/2008/IHS-CERA-Power-Capital-CostsIndex.htm (last accessed June 20, 2008)

International Energy Agency (IEA). 2000. "Experience Curves for Energy Technologies." Paris, France: International Energy Agency.

International Energy Agency (IEA). 2007. "World Energy Outlook 2007.” Paris, France: International Energy Agency.

Junginger, M., Faaij, A. and W.C. Turkenburg. 2005. "Global Experience Curves for Wind Farms." Energy Policy, 33: 133-150.

Lusey, N. and D. Sperling. 2008. "America's Bottom-up Climate Change Mitigation Policy." Energy Policy, 36: 673-685.

Kobos, P., Erickson, J. and T. Drennen. 2006. "Technological Learning and Renewable Energy Costs: Implications for US Renewable Energy Policy.” Energy Policy, 34 (13): 1645-1658.

McDonald, A. and L. Schrattenholzer. 2001. "Learning Rates for Energy Technologies." Energy Policy, 29: 255-261.

Neij, L. 1997. "Use of Experience Curves to Analyze the Prospects for Diffusion and Adoption of Renewable Energy Technology.” Energy Policy, 23 (13): 1099-1108.

Neij, L. 2008. "Cost Development of Future Technologies for Power Generation - A Study Based on Experience Curves and Complementary Bottom-up Assessments." Energy Policy, 36: 2200-2211.

Nemet, G. 2006. "Beyond the Learning Curve: Factors Influencing Cost Reductions in Photovoltaics." Energy Policy, 34 (17): 3218-3232.

Papineau, M. 2006. "An Economic Perspective on Experience Curves and Dynamic Economies in Renewable Energy Technologies.” Energy Policy, 34: 422-432. 
U.S. Department of Energy. 2008. 20\% Wind Energy by 2030: Increasing Wind Energy's Contribution to U.S. Electricity Supply. DOE/GO-102008-2567. Washington, D.C.: U.S. Department of Energy. http://www1.eere.energy.gov/windandhydro/pdfs/41869.pdf (last accessed June 20, 2008)

Wiser, Ryan and Galen Barbose. 2008. Renewables Portfolio Standards in the United States: A Status Report with Data Through 2007. LBNL-154E. Berkeley, Calif.: Lawrence Berkeley National Laboratory. http://eetd.lbl.gov/ea/ems/reports/lbnl-154e-revised.pdf (last accessed June 20, 2008)

Wiser, Ryan and Mark Bolinger. 2008. Annual Report on U.S. Wind Power Installation, Cost, and Performance Trends: 2007. LBNL-275E. Berkeley, Calif.: Lawrence Berkeley National Laboratory. http://eetd.lbl.gov/ea/ems/reports/lbnl-275e.pdf (last accessed June 20, 2008)

Wiser, Ryan, Mark Bolinger, Galen Barbose. 2007. "Using the Federal Production Tax Credit to Build a Durable Market for Wind Power in the United States" The Electricity Journal. Vol 20, Issue 9, November 2007, pp. 77-88. 